\title{
Sandoz-funded research from Rhine spill suggests blockages are worse than toxins
}

\begin{abstract}
Basel \& Munich. A river can quickly recover from 'catastrophic' pollution, even on the scale of the 1986 Rhine disaster, but it cannot recover from engineering projects that obstruct its flow. This unexpected discovery was made possible by a SFr 10 million (US\$7.7 million) fund set up by the Swiss chemical company Sandoz as a public apology for causing Europe's worst episode of river pollution.
\end{abstract}

A fire that destroyed one of its chemical storage depots near the Rhine and caused chemicals such as mercury, disulfon and thiometon to leak into the river damaged the reputation of Sandoz along with the Rhine's ecosystem. Environmental authorities from the four countries through which the Rhine flows - Germany, Switzerland, France and the Netherlands - were hindered by a lack of basic information.

The 'Rhine fund', which has supported 36 independently reviewed projects over a five-year period, was intended to provide a more accurate picture for the future and, although originally castigated as 'guilt money', appears now to have been money well-spent. The work it has funded suggests that the impact of the damage was not as great as predicted.

Researchers found that the colloidal nature of the Rhine's water protected it from the full impact of the poison. The high levels of inorganic particles in the Rhine, constant throughout the year, adsorbed much of the poison, limiting its effective concentration.

In addition, studies of microinvertebrate populations, indicators of the ability of a river to support life, showed the river's natural ability to recover, provided that it had not been unnaturally engineered. The poison destroyed populations of the microinvertebrates downstream of Basel, but within three years their densities and varieties had returned to pre-accident levels. Conversely, the microinvetebrates failed to return upstream of Basel, an area unaffected by the Sandoz poisoning but obstructed by technical barriers. The obstructed flow caused their habitat, interstitial spaces in the river bed, to become filled with fine mud and decimated the population.

Researchers also found that regeneration of fauna populations comes not from the Rhine itself but from tributaries whose beds act as efficient reservoirs of life. This helps to explain why a section of the Rhine in France whose tributaries were all blocked during the last century has not yet fully recovered.

"While we're not saying that anyone should deliberately pollute rivers, we have always suspected that it would be worse to block a river than to poison it", says Ivan Tomka of the University of Fribourg in Switzerland. But Tomka fears that governments may ignore an important political question raised by these findings: to what extent should ecological considerations be pitted against the desire of industry and agriculture to tame the river?

Other research supported by the Rhine fund, which was distributed by an independent board of reviewers to scientists in the four countries through which the Rhine flows, revealed a surprising diversity of fish and fauna species. Ecologist Markus Ritter of Basel says that the Sandoz money, small by most standards, brought a "surprising advance in understanding of a much-neglected field."

But the end of support from Sandoz has left some projects in limbo. A plan to establish an international database for Rhine ecology was narrowed to a catalogue of data sources when it became clear that political and legal problems would make it hard to collect the data. The catalogue was compiled two years ago by the Institute for European Environmental Policy, an independent nonprofit organization based in Paris, but has remained uncomputerized and the information is still not freely accessible.

Since the accident, Sandoz has improved its safety standards and increased its investment in environmental protection from SFr66 million in 1987 to more than SFr200 million today. But it has no plans to set up a successor to the Rhine fund.

Oliver Klaffke and Alison Abbott

\section{Science fares well in tight 1993 French budget}

Paris. Science emerged relatively unscathed from the austere French budget for 1993 announced earlier this month. The proposed FF53.7 billion (US $\$ 11$ billion) budget for civil research and development is up 5.25 per cent more than the overall growth of 3.4 per cent in public expenditure. For the second year in a row, research organizations also are virtually the only public bodies spared from retroactive reductions.

Why is that? Research has been a national priority for the Socialist government since it came to power in 1981, and funding for research has grown from 1.97 per cent of gross national product (GNP) in 1981 to 2.4 per cent in 1990. Although the government has fallen short of its target of 3 per cent of GNP, the growth has been enough to keep France in fourth place worldwide behind Japan, the United States and Germany.

Much of the credit goes to Hubert Curien, whose ministry of research and space has developed a coherent long-term national policy, recruited talent, prodded research organizations into becoming more efficient and encouraged industry to carry out more research through subsidies, tax credits and the like. In turn, industry has spent a record amount on research for the past four years, some 1.1 per cent of GNP, at the same time reducing advertising budgets by 30 per cent.

This year's budget continues the themes of past years, although support for industrial research has been somewhat curtailed. The Centre Nationale de la Recherche Scientifique (CNRS), the country's largest research organization, must make do with a proposed increase of only 4.5 per cent, to FF12.4 billion, compared with 8.1 per cent last year. In contrast, the budgets of the space research organization (CNES) and the medical research organization (INSERM) are scheduled to be increased by 7.5 per cent and 6.6 per cent.

The French atomic research agency, which has had its budget reduced steadily over the past few years, received a proposed increase of 3.8 per cent to FF 6.4 billion. Ministry officials feel that the agency has undergone sufficient reforms to merit renewed support. The decision to reinvest is linked to an increased emphasis on safety, cleaner fuels and the technological challenges of dismantling reactors while research into plant physiology will be phased out during the next three years and work on protein engineering will continue only as collaborative projects with other organizations.

Among the smaller organizations, the National AIDS agency received a proposed increase of 10.5 per cent in its budget. while the Centre d'Etude du Polymorphisme Humain (CEPH) will have its budget increased by 40 per cent.

The creation of scientific jobs is another priority for the French government. Next year's budget promises to add 470 jobs, bringing to 1,625 the number of new positions created since 1988 .

Declan Butler 